\title{
Wizja korytarza czesko-rosyjskiego według polskich map z 1920 roku
}

\section{Piotr Eberhardt}

$\mathrm{Na}$ początku brzemiennego $\mathrm{w}$ przełomowe wydarzenia 1920 r. ukazała się w Warszawie publikacja pt. „Niebezpieczeństwo korytarza czesko-rosyjskiego" ${ }^{\text {. }}$ Zawierała ona przedruki artykułów, które ukazały się w ówcześnie wychodzących czasopismach i gazetach polskich, poświęcone uwarunkowaniom politycznym południowej granicy Polski. Starano się w nich określić konsekwencje geopolityczne, jakie mogą mieć miejsce w przyszłości na terytorium położonym po południowej stronie Karpat. Sytuacja bowiem na obszarze byłego Cesarstwa Austro-Węgierskiego była niestabilna, traktatowo nieuregulowana i groziła różnorodnymi konfrontacjami etnicznymi. Oczekiwano zwłaszcza decyzji wielkich mocarstw zachodnich w kwestii węgierskiej i definitywnego ustalenia granic tego państwa.

Zamieszczone w książce artykuły, w liczbie 33, zebrano i przedrukowano z następujących periodyków: „Wiadomości Polskie”, „Gazeta Warszawska”, „Czas”, „Kurier Poranny”, „Dziennik Powszechny”, „Nowa Reforma”, „Goniec Krakowski”, „Kurier Lwowski”, „Tygodnik Ilustrowany”, „Głos Polski”. Z wyjątkiem trzech autorów (Jan Dąbrowski, Tadeusz Święcicki, Roman Halicki) artykuły sygnowane były pierwszą literą imienia i nazwiska (np. J.D, B.W, W.Cz, A W- ski, t.t., D.R) lub pseudonimem (Vistulensis, Historicus). Trudno jest obecnie wytłumaczyć dlaczego były przeważnie anonimowe ${ }^{2}$.

Częścią integralną przypomnianego opracowania były dwie kolorowe mapy (czerwono-białe) ukazujące rozgraniczenia polityczne na rozległym terytorium, zawartym w przybliżeniu między Bałtykiem a Morzem Czarnym

${ }^{1}$ Niebezpieczeństwo korytarza czesko-rosyjskiego. Konieczność granicy polsko-węgierskiej. Co mówi o tem prasa polska, Warszawa 1920.

2 Analizowana publikacja była już odnotowana w polskiej literaturze przedmiotu: M.K. Kamiński, Konflikt polsko-czeski 1918-1921, (patrz mapa 1 i 2). Dwa ujęcia kartograficzne oraz strona tekstowa, składająca się z tak wielu artykułów prasowych, są interesujące dla badaczy, ze względu na czas ich powstania, myśl ideową, która im przyświecała oraz stosowaną argumentację faktograficzną. Nie utraciły one swojej wymowy geopolitycznej, odzwierciedlając poglądy nie tylko społeczeństwa polskiego, ale i - sądzić można - również ówczesnej elity przywódczej kraju na wydarzenia, jakie zachodziły po południowej stronie granicy Polski. Było to już po werdykcie wersalskim, który między innymi zadecydował o zachodnich granicach Polski oraz wytyczył granicę niemieckoczeską oraz czesko-austriacką. Nie zapadły jeszcze ostateczne decyzje co do przyszłych granic pokonanych Węgier, gdyż było to przed traktatem wielkich mocarstw $\mathrm{w}$ Trianon (4 czerwca 1920 r.), w którym terytorium Węgier zostało zredukowane do $1 / 3$ swojej poprzedniej wielkości. Mapy zawarte w książce zostały wykreślone i opublikowane w trakcie wojny polsko-bolszewickiej. Zachodnia granica Polski była zgodna $\mathrm{z}$ ustaleniami wersalskimi, $\mathrm{w}$ tym orientacyjnie włączono Opolszczyznę i dużą część Mazur i Warmii, o których losie miał zadecydować przyszły plebiscyt. Wschodnia granica Polski odzwierciedlała w przybliżeniu linię frontu polsko-bolszewickiego istniejącą na przełomie 1919 i 1920 r. Włączono do Polski: Białoruś, Litwę, Łatgalię, czyli Inflanty Polskie, zachodni Wołyń oraz Galicję. Tę ostatnią w dwóch wariantach granicznych.

Ustalenie południowej granicy Polski w przyjętej skali nie wymagało specjalnej inwencji. Było bowiem wiadomo, że będzie ona przebiegała mniej więcej grzbietem Karpat i będzie

Warszawa 2001 oraz H. Walczak, Stanowisko polskich ugrupowań politycznych wobec Czechostowacji w latach 1918-1925, Szczecin 1999. W pierwszej z tych książek omawiane mapy zostały zamieszczone w tekście i na okładce. 


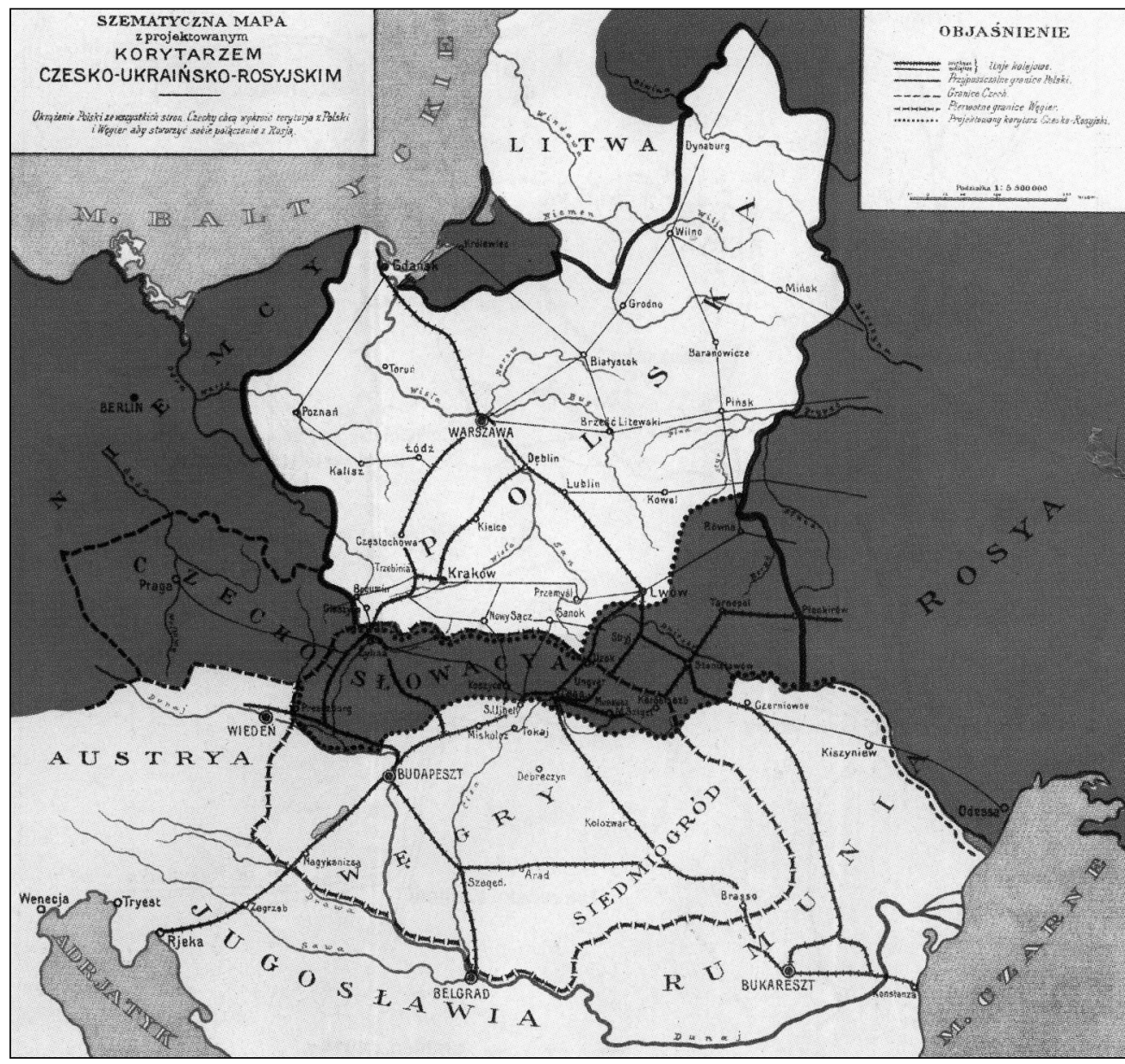

Mapa 1. Mapa z projektowanym korytarzem czesko-rosyjskim.

Źródło: „Niebezpieczeństwo korytarza czesko-rosyjskiego. Konieczność granicy polsko-węgierskiej. Co mówi o tem prasa polska", Warszawa 1920

w miarę zgodna z byłą granicą I Rzeczypospolitej, a następnie z rozgraniczeniem między Królestwem Węgierskim a autonomiczną Galicją. Nierozstrzygnięta była jeszcze kwestia przynależności Śląska Cieszyńskiego oraz Orawy i Spisza, ale te kwestie, chociaż wówczas głośne, miały charakter drugorzędny.

Niepewna była, jak wspomniano, przyszłości Węgier. Nierozstrzygnięta była jeszcze przynależność północnych komitatów węgierskich położonych na południowych zboczach Karpat. Pretendowały do ich posiadania dwa państwa mające wówczas inny status prawny i siłę polityczną (Węgry i Czechy). Pierwsze z nich, podobnie jak Niemcy i Austria, było traktowane jako państwo militarnie pokonane. Zakładano, że Węgry będą zmuszone do przyjęcia bezwarunkowo werdyktu państw Ententy. Drugie z nich, Czechy, dzięki zdolnościom swoich przywódców, głównie zaś Masaryka, znalazły się w grupie państw zwycięskich. Dla uzasadnienia postulatów terytorialnych Czechy wysuwały odmienną od Węgier argumentację i była ona zazwyczaj akceptowana przez aliantów zachodnich. Spór między obu państwami dotyczył przynależności politycznej tzw. Górnych Węgier i Rusi Węgierskiej, czyli ziem słowackich i rusińskich. Nie można 


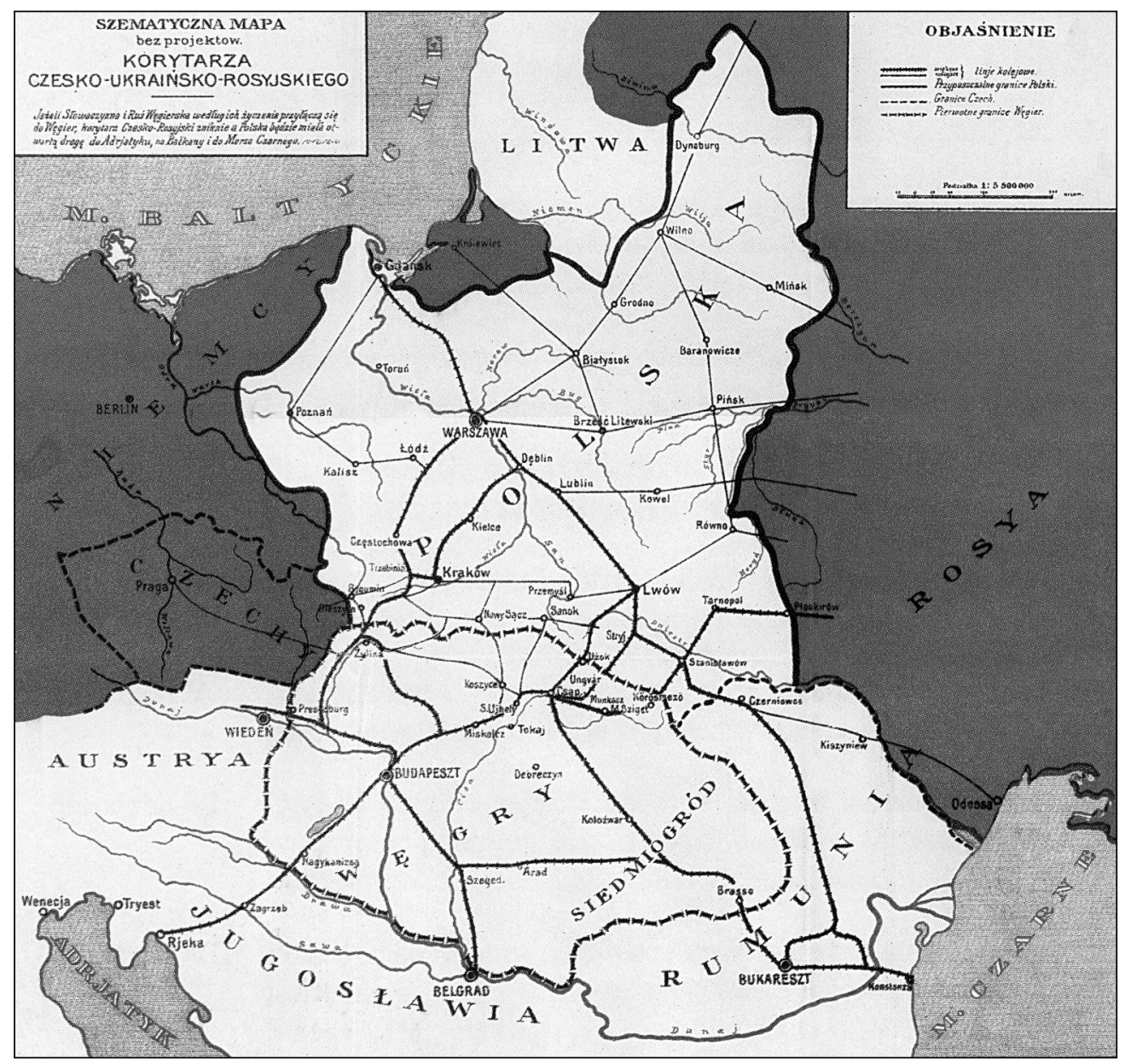

Mapa 2. Mapa bez projektowanego korytarza czesko-rosyjskiego.

Źródło: „Niebezpieczeństwo korytarza czesko-rosyjskiego. Konieczność granicy polsko-węgierskiej. Co mówi o tem prasa polska", Warszawa 1920

było kwestionować, że obie prowincje należały od tysiąca lat do Królestwa Węgierskiego. Na większości tych obszarów przeważała jednak ludność rodowodu słowiańskiego tzn. Słowacy i Rusini. Poddawani byli oni intensywnej madziaryzacji i, będąc dyskryminowanymi liczyli, że dzięki wsparciu państwa czeskiego pojawi się możliwość utworzenia federacyjnego państwa czechosłowackiego, które zapewni Słowakom i Rusinom równouprawnienie polityczne i narodowe. $\mathrm{Z}$ tego też powodu strona czeska wykorzystywała argumenty etniczne.

W powstałej sytuacji nabierał znaczenia problem rozgraniczenia ludności węgierskiej od słowackiej i rusińskiej. Na górzystych obszarach północnych dominowała ludnośćsłowiańska, zaś na południowych terenach nizinnych przeważała ludność węgierska. Sprawa była skomplikowana, gdyż występowały również obszary mieszane narodowościowo. W momencie publikacji omawianej książki (zawierającej wspomniane mapy) czesko-węgierski spór graniczny czekał na bliskie już rozwiązanie. $Z$ punktu widzenia prawa międzynarodowego sporny obszar formalnie należał jeszcze do państwa węgierskiego, ale oczekiwano, że ostateczna decyzja mocarstw zachodnich będzie niekorzystna dla Węgier i nastąpi utworzenie federacji czesko-słowacko-rusińskiej. 
Pewna niepewność i związane z tym emocje były powodem licznych spekulacji i tworzenia alternatywnych koncepcji geopolitycznych. Dowodem tego stanu jest prezentowane opracowanie tekstowe i kartograficzne. Zawiera ono poglądy wygłaszane przez polskich publicystów. Sprawa przyszłości Węgier była im bliska i sprzyjali oni wszelkim terytorialnym postulatom Budapesztu. Prezentowany zbiór artykułów ma charakter prowęgierski i zdecydowanie antyczeski. O fobii antyczeskiej świadczy tekst zawarty $\mathrm{w}$ programowej przedmowie, który warto wiernie zacytować: „Między Węgry a Polskę wcisnęły się Czechy, o których najdawniejszy z kronikarzy polskich Gallus powiada: 'Bohemi sunt Polorum infestissimi inimici' (Czesi są najzawziętsztymi wrogami Polaków). Stwierdzają zresztą tosamo Kadłubek i Długosz. Zamiast więc, żeby Polska południową granicą stykała się z przyjaznymi sobie Węgrami, miejsce tych ostatnich na stokach Karpat zają ów naród, którego królowie narzucali się, nieproszeni na tron Polski i zajęli go też przez pewien czas: ów naród przeciwko, któremu Piastowie tyle walczyli i który Łokietek dopiero z pomocą Węgrów zdołał z Polski usunąć. Naród, który za dni absolutyzmu austriackiego przeprowadzał najgorliwiej germanizacje Galicji - dziś nowem niebezpieczeństwem zagraża Polsce: owym osławionym 'korytarzem czesko-rosyjskim'. Tratując włości węgierskie, słowackie, tudzież Rusinów węgierskich - pragnie utworzyć sobie bezpośredni, sztuczny łącznik z Rosją, dla tem łatwiejszego zrealizowania gorączkowych rojeń imperialistycznych i panslawistycznych majaków. Piekielny ten plan Czechów - pozbawiony zresztą wszelkiej, zarówno historycznej, jak etnograficznej podstawy - jest dla Polski najgroźniejszym niebezpieczeństwem: godzi on bowiem w najżywotniejsze jej interesy, krojąc na to, ażeby ją odciąć od wspólnej granicy z Węgrami, która według świadectwa tysiącletniej historii naszego wspólnego rozwoju, jak niemniej współczesnych wymogów ekonomicznych, jest conditio sine qua non dla rozwoju sił żywotnych Polski. Prócz tego - takie okrążenie pierścieniem wrogich żywiołów byłoby równoznaczne dla Polski ze zduszeniem"”.
Pomijając archaiczną stylistykę oraz demagogiczną i skrajnie tendencyjną retorykę przytoczonego cytatu, sformułowane przesłanie pod względem ideowym i terytorialnym jest jednoznaczne. Bez wątpienia jest apelem nawołującym do sojuszu Polski z Węgrami przeciwko Czechom, w celu utworzenia wspólnej granicy polsko-węgierskiej. Ona jedynie jest w stanie zapewnić Polsce bezpieczeństwo. W przeciwnym przypadku, to znaczy po włączeniu ziem słowackich i rusińskich do Czech, utworzy się korytarz terytorialny łączący Niemcy z Rosją, co w efekcie doprowadzi do okrążenia Polski przez państwa wrogo nastawione do państwowości polskiej. Dla udowodnienia tej, tak krańcowo ujętej, tezy politycznej redaktorzy tomu zebrali w sposób selektywny artykuły z prasy polskiej, które podzielały tego rodzaju subiektywną postawę wobec południowych sąsiadów Polski. Dla wzmocnienia argumentacji książka jest poprzedzona wyjaśniającym wprowadzeniem oraz zakończona obszernym komentarzem merytorycznym. Miała ona wyraźny cel propagandowy, zmierzała do stworzenia w Polsce atmosfery społecznej sprzyjającej interesom węgierskim i wytworzeniu negatywnego nastawienia do wszelkich postulatów czeskich. Wiadomo było, że Polska nie miała żadnych możliwości oddziaływania na państwa zachodnie i jej stanowisko nie miało żadnego wpływu na przygotowywany werdykt dotyczący delimitacji granicy czechosłowacko-węgierskiej.

Z odległej perspektywy czasowej omawiane opracowanie ma istotne znaczenie poznawcze. Głoszone wówczas przez prasę polską poglądy są reprezentatywne i są w stanie wyjaśnić wiele dylematów, jakie stały przed polską polityką zagraniczną. Pokazują również nastawienie polskich środków masowego przekazu, które w dużym stopniu odzwierciedlały opinie społeczeństwa polskiego. Z punktu widzenia geopolitycznego są godne przypomnienia, gdyż na podstawie analizy współczesności kreują wyrazisty scenariusz przyszłych wydarzeń politycznych.

\footnotetext{
${ }^{3}$ Niebezpieczeństwo korytarza czesko-rosyjskiego, s. 4-5.
} 
Zadaniem, do którego zmierzali redaktorzy opracowania, było przekonanie polskiego czytelnika, że włączenie ziem słowackich i rusińskich do tworzonego państwa czechosłowackiego doprowadzi do powstania korytarza czesko-rosyjskiego, co $\mathrm{w}$ rezultacie przyniesie katastrofalne konsekwencje dla przyszłości Polski. Ta kluczowa hipoteza uzasadniona jest względami wojskowymi, politycznymi i ekonomicznymi. Z punktu widzenia wojskowego potencjalny korytarz czesko-rosyjski zagrażał Śląskowi Cieszyńskiemu oraz całej południowej granicy Polski, w tym głównie wschodniej Galicji, gdyż: „czesko-rosyjska polityka dąży do tego, żeby poprzez obszar ziemi słowackiej i Rusi Węgierskiej utworzyć bezpośrednią styczność z Rosją. Dopóki ziemia słowacka i Ruś Węgierska będą pozostawały w rękach czeskich - dopóty czesko-rosyjska polityka stale pracować będzie nad tem, aby Wschodnia Galicja dostała się w ręce Ukraińców albo Rosyan, i żeby korytarz czesko-rosyjski stał się faktem spełnionym. Co więcej - bardzo być może, iż Rosyanie i Czesi przeprowadzą przez korytarz ów tranwersalną linię kolejową: ponieważ jednak przez terytorium korytarza impreza ta napotkałaby dużo technicznych trudności z powodu Karpat, więc przypuszczalnie zwrócą uwagę na dwie linie kolejowe na północ od Karpat, wiodące z zachodu na wschód"4.

Uwypuklono w rozpatrywanym tekście również negatywne skutki polityczne, które wystąpią po opanowaniu ziem słowackich i rusińskich przez państwo czeskie, a mianowicie:

- Czesi zamierzają sczechizować Słowaków, co doprowadzi do ich wrogiego stosunku do Polski,

- warunki życia narodowego orawskich i spiskich Polaków ulegną pogorszeniu,

- dzięki opanowaniu tzw. Rusi Węgierskiej przez Czechy uzyska poparcie ukrainizm i moskalofilizm,

- nastąpi odcięcie Polski od Austrii, Węgier, Rumunii, Serbii i Bułgarii,

- powstanie korytarza czesko-rosyjskiego zostanie wykorzystane przez Niemcy jako droga do współpracy politycznej z Rosją,
- uformowana łączność polityczno-terytorialna będzie korzystna dla Rosji i Ukrainy, - utrata przez Węgry Rusi Zakarpackiej będzie wstępnym krokiem do połączenia jej z Galicją Wschodnią i oddania Ukrainie lub Rosji.

Mniejszą uwagę autorzy zwrócili na aspekty ekonomiczne, które trudniej odwzorować na mapie, ale też uwypuklono konsekwencje utworzenia bariery dla polskiego eksportu do krajów leżących nad Adriatykiem i Morzem Czarnym. Odcięcie to doprowadzi do blokady współpracy gospodarczej Polski z południowowschodnią częścią kontynentu europejkkiego. Sprecyzowano to w sposób następujący: „Siedem ważnych linji kolejowych prowadzi z Polski do Węgier przez Karpaty. Jest to nader ważna droga Polski na południe ku Adriatykowi. Niestety z powodu imperialistycznej polityki Czech drogi te są dla Polski zamknięte, polskie linie komunikacyjne ku Węgrom odcina samowolnie rząd czeski i od jego dobrego humoru zdaje się zależeć na przyszłość, czy polskie transporty przepuści przez swe słowackie terytorium czy nie. Równocześnie planowany korytarz czesko-rosyjski oderwie Polsce Galicje Wschodnią i odetnie ją od Rumunii, czyli pozbawi państwo polskie koniecznej i niezwykle ważnej arterii komunikacyjnej, bezpośredniego połączenia z Morzem Czarnym"”.

Podane i uzasadnione potencjalne zagrożenia, ukazane na mapach, są podstawą zmierzającą do udowodnienia tezy, że w interesie Polski jest zachowanie wspólnej granicy polskowęgierskiej i pozostawienie etnicznych ziem słowackich i rusińskich w ramach przyjaznego Polsce państwa węgierskiego. Autorzy przypominają, że przez cały okres historyczny granica polsko-węgierska łączyła dwa bliskie narody, które żyły w przyjaźni i współpracy. Opanowanie tego strategicznego obszaru przez Czechy przyniesie istotne konsekwencje geopolityczne a mianowicie: „Najnowsze plany czeskie zwracają się już wprost przeciwko najżywotniej-

\footnotetext{
4 Tamże, s. 168.

5 Tamże, s. 126-127.
} 
szym interesom Polski. Czesi chcą odgrywać pierwszą rolę w Europie środkowo-wschodniej i dlatego dążą do usunięcia jedynego na razie groźnego rywala - Polski, której siłę pragnęliby osłabić - Jednocześnie Czesi posuwając się na Węgrzech północnych ku wschodowi odcinają swemi posiadłościami Polskę od komunikacji z południem. Przez projekty zaś usadowienia się na Podkarpaciu zmierzają do wytworzenia terytorialnej łączności z Ukrainą. W tym wypadku chodzi im o bezpośrednią drogę dla swego eksportu przemysłowego do Rosji z pominięciem Polski. Dlatego popierają chwilowo plany ukraińskie oderwania od Polski Galicji Wschodniej, która ma służyć za pomost dla ekspansji czeskiej w Rosji”'.

Dołączona do tekstu ilustracja kartograficzna w postaci dwóch map pokazuje możliwe warianty przyszłościowe. Pierwszy z nich, niekorzystny, a według autorów katastroficzny dla Polski, czyli uformowanie się terytorialnego korytarza czesko-rosyjskiego, oraz drugi, w którym uda się utworzyć barierę oddzielającą Czechy od Ukrainy. Zakładając zaś nieukonstytuowanie się niepodległej Ukrainy nastąpi bezpośrednie połączenie terytorialne Czech z bardziej odległą Rosją. Na obu mapach jednolitym kolorem czerwonym oznaczono Niemcy, Czechy i Rosję, zaś białym państwa pozostałe tworzące wspólny lub rozdzielony blok między Bałtykiem a Morzem Czarnym i Adriatykiem. W wariancie pierwszym większa część wschodniej Galicji (ale bez Lwowa), Słowacja, Ruś Zakarpacka i Czechy tworzą korytarz między Niemcami i Rosją. W drugim zaś, tym optymalnym według autorów wariancie, cała wschodnia Galicja należy do Polski, zaś Słowacja i Ruś Zakarpacka do państwa węgierskiego. Bardzo już bliska przyszłość ujawniła, że żaden $\mathrm{z}$ tych krańcowych wariantów nie został urzeczywistniony. Zabrakło autorom wyobraźni, nie przewidzieli, że może pojawić się wariant pośredni, to znaczy taki, że pomimo utraty przez Węgry Słowacji i Rusi Zakarpackiej, korytarz między Czechami i Rosją zostanie zablokowany przez Polskę i Rumunię.

Wymowa ideowa i polityczna opracowania, a zwłaszcza map, była wymierzona przeciwko wszelkim aspiracjom czeskim, a również słowackim i miała charakter zdecydowanie antyczeski. Tak też została przyjęta przez władze nowopowstałego państwa czeskiego. Można sądzić, że konflikt o Śląsk Cieszyński był przyczyną tego emocjonalnego nastawienia polskich publicystów. Delegat rządu czeskiego w Warszawie - Rudinsky powiadomił swoich zwierzchników w Pradze o wydanej publikacji, zwracając uwagę na jej antyczeski wydźwięk polityczny. Całe polskie opracowanie zostało następnie omówione i skomentowane 27 kwietnia 1920 r. na łamach partyjnego organu czeskiej narodowej demokracji „Narodni listy". Zamieszczono w tekście czeskim dwie polskie mapy oraz w sposób w miarę rzeczowy, ale ostry, odpowiedziano na polskie zarzuty. Skrytykowano tendencyjną i histeryczną formę oraz styl polskich wypowiedzi. Uznano, że strategiczne cele czeskiej polityki zagranicznej zostały przez Polaków prawidłowo odczytane, ale są one zgodne z czeską racją stanu i interesami Słowaków i Rusinów. Ta prasowa polemika świadczyła o pogarszających się stosunkach polsko-czeskich ${ }^{7}$.

Nie wnikając w ówczesne dość złożone stosunki polsko-czeskie, należy zastanowić się czy polscy publicyści prezentując swoje wizje i koncepcje na przełomie 1919/1920 r. potrafili wznieść się ponad osobiste urazy i w sposób właściwy, i przemyślany ocenili zagrożenie geopolityczne Polski wynikające z mitycznego korytarza czesko-rosyjskiego. Odpowiedź jest trudna, gdyż układ zdarzeń nie był taki, jak wyobrażali sobie polscy obserwatorzy ówczesnej sceny politycznej. Państwo węgierskie niebawem utraciło ziemie słowackie i rusińskie na rzecz Czechosłowacji. Pomimo tego terytorialny korytarz czesko-rosyjski nie powstał. Został on, jak wspomniano, zagrodzony poprzez przyłączanie do Polski całej Galicji aż po rzekę Zbrucz, zaś do Rumuni całej historycznej Bukowiny. Powstała wspólna granica polsko-rumuńska, która odcięła Ruś Zakarpacką od sowieckiej Ukrainy, czyli Czechosłowacja

6 Niebezpieczeństwo korytarza czesko-rosyjskiego, s. 17.

7 M.K. Kamiński, Konflikt polsko-czeski, s. 274. 
nie mogła już graniczyć z ZSRR. Postulowana przez Polaków wspólna granica polsko-węgierska w ówczesnych warunkach nie miała szans na realizację. Powstała dopiero w $1938 \mathrm{r}$. i pomimo oczekiwań nie mogła odegrać poważniejszej roli politycznej. Można sądzić, że gdyby powstała wcześniej to też jej znaczenie byłoby znikome.

Późniejsze lata udowodniły, iż tzw. korytarz czesko-rosyjski nie był potrzebny do pokonania i podziału Polski. Pakt zawarty między Ribbentropem a Mołotowem w dniu 23 sierpnia 1939 r. nie wymagał połączenia terytorialnego między obu agresorami. Likwidacja rok wcześniej Czechosłowacji ułatwiła to porozumienie, gdyż Niemcy były na tyle wzmocnione, że mogły bagatelizować postawę mocarstw zachodnich, a dalszy los Polski był już przesądzony. Utworzenie zaś marionetkowego państwa słowackiego ułatwiło niemiecki atak na Polskę. Istnienie Polski uzależnione było od relacji między Berlinem a Moskwą. Działo to się wyłącznie w układzie równoleżnikowym. Sytuacja po południowej stronie Karpat miała znaczenie drugorzędne i była podporządkowana porozumieniom sowiecko-niemieckim. Trudno wyrokować czy ewentualne powstanie po I wojnie światowej korytarza czesko-rosyjskiego mogłoby wpłynąć na późniejszy werdykt monachijski. Można przypuszczać, że pomimo wykorzystywania wówczas przez władze sowieckie retoryki antyniemieckiej, Stalin był zainteresowany obaleniem porządku wersalskiego. Podobnie w skrzywdzonych przez mocarstwa zachodnie Węgrzech istniał silny rewizjonizm skierowany przeciwko Czechosłowacji i Rumunii. Groziło to też konfliktem militarnym, który jednak również był pod kontrolą niemiecką. Bezpośrednio po I wojnie światowej wiele kwestii było niewyklarowanych i trudnych do przewidzenia. Wszystko to razem wymaga ostrożnej interpretacji opracowania powstałego w wyniku kolektywnej pracy polskich autorów w 1920 r. Nie byli oni w stanie przewidzieć w pełni przyszłości, nie tylko na południowym pograniczu Polski. Znajdowali się pod naciskiem doraźnych problemów politycznych i nie zawsze byli w stanie oddzielić kwestie priorytetowe od marginalnych.

Nie znaczy to, że omawiane opracowanie nie jest godne przypomnienia i oceny merytorycznej. Odznacza się ono oryginalnością, mało jest tego typu tekstów w polskiej literaturze z zakresu geografii politycznej. Większość polskich studiów dotyczy naszej granicy zachodniej lub wschodniej oraz stosunków polsko-niemieckich, polsko-rosyjskich względnie relacji polsko-ukraińskich czy polsko-litewskich. Niewiele jest prac poświęconych uwarunkowaniom geopolitycznym polskiej granicy południowej oraz krajom znajdującym się po drugiej stronie Karpat. Pomimo subiektywizmu i swoistego determinizmu rozprawa jest konsekwentna i logiczna. Odznacza się dociekliwością, tak w wymiarze analitycznym jak syntetycznym i może stanowić podstawę do różnorodnych studiów porównawczych z zakresu tzw. geopolityki alternatywnej. Załączone dwie mapy są także nowatorskie i pokazują konsekwencje dwóch odmiennych wariantów, w tym jednego scenariusza niebezpiecznego dla państwowości polskiej. Nie został on z wielu powodów spełniony, ale nie można negować, że istniały siły polityczne zainteresowane jego realizacją. Z punktu widzenia metodycznego i faktograficznego zarówno ujęcie tekstowe jak i kartograficzne posiada wiele walorów poznawczych i reprezentuje istotną wartość naukową. W treści konceptualnej nawiązuje do najbardziej interesujących opracowań geopolitycznych powstałych bezpośrednio po I wojnie światowej, gdy kształtowały się zręby polskiej polityki zagranicznej. 


\section{A vision of the Czech-Russian corridor according to Polish maps from 1920}

\section{Summary}

The article analyzes the content of the book which was published in Warsaw at the beginning of 1920. It was devoted to the possibilities of realization of a territorial corridor between Germany and Russia and the potential consequences of its creation. The idea appeared after the decisions taken at the Paris Peace Conference signed in Versailles (28 June 1919), but before the decisions of the Entente powers in Trianon (4 June 1920), which set the political borders of Hungary. In that situation it was not yet known whether Poland would border with Hungary in the south or with Czechoslovakia. The aforementioned publication collected 33 articles related to that uncertainty. They appeared at the turn of 1919 and 1920 on the pages of Polish periodicals. They were concerned with geopolitical repercussions that the decisions of the great powers had for Poland regarding the course of the borderline on the southern side of the Carpathian Mountains. Two potential scenarios of events were considered. They were presented on two maps, which constitute an integral part of the present article. The first variant assumed including the Slovak and Ruthenian lands into Czechia. The other maintained the existing political structure, together with the common Polish-Hungarian border. The first variant provided for the possibility of creating a territorial corridor connecting Germany with Russia and running through the territories of Czechoslovakia and Ukraine. The authors opted for the second solution, which was supposed to be much more beneficial for Poland. They justified it with military, political and economic reasons. The near future showed that neither of those two variants was realized since Hungary lost the Slovak and Ruthenian lands, and the corridor between Soviet Russia and Czechoslovakia was blocked by the territories of Poland and Romania. Despite that missed project, the publication under discussion is of great historical value and it is a significant achievement of the Polish geopolitical thought.

Słowa kluczowe: geografia historyczna, geopolityka, korytarz czesko-rosyjski

Keywords: historical geography, geopolitics, Czech-Russian corridor

prof. dr hab. Piotr Eberhardt - pracownik Zakładu Przestrzennego Zagospodarowania w Instytucie Geografii i Przestrzennego Zagospodarowania Polskiej Akademii Nauk, przewodniczący Rady Naukowej Instytutu Geopolityki

(e-mail: p.ebe@twarda.pan.pl) 